\title{
Borderline Tumors of the Ovary: Clinical Course and Prognostic Factors
}

\author{
Nina Ewald-Riegler ${ }^{\mathrm{a}}$ Oya du Bois ${ }^{\mathrm{a}} \quad$ Annette Fisseler-Eckhoff ${ }^{\mathrm{b}} \quad$ Friedrich Kommoss $^{\mathrm{c}}$ \\ Philipp Harter ${ }^{a, d}$ Alexander Traut ${ }^{a, d}$ Rita Hils $^{a} \quad$ Andreas du Bois ${ }^{a, d}$ \\ aKlinik für Gynäkologie und Gynäkologische Onkologie, \\ ' IPZ Institut für Pathologie und Zytologie, HSK, Dr. Horst Schmidt Klinik GmbH, Wiesbaden, 'Institut für Pathologie, Mannheim, \\ ${ }^{\mathrm{d} K l i n i k}$ für Gynäkologie und Gynäkologische Onkologie, Kliniken Essen Mitte, Essen, Deutschland
}

\section{Keywords}

Borderline ovarian tumors · Outcome

\section{Summary}

Background: The prognosis in borderline tumors of the ovary (BOT) is generally favorable. However, some patients experience recurrence, and mortalities occur. There is a need to better characterize prognostic factors to be considered for individualized treatment planning. Patients and Methods: The data of 158 consecutive patients who underwent surgery for BOT at a tertiary referral center for gynecologic oncology between 1997 and 2008 were retrospectively analyzed. Results: Most patients had early stage disease, and advanced stages FIGO II/III only occurred in $23.4 \%$. Serous histology was most frequent (68\%), followed by mucinous histology (22\%). All patients received surgery as initial treatment with no adjuvant systemic therapy. 37 patients $(40.7 \%$ of the patients under the age of 50) had fertility-sparing surgery (FSS). Recurrent disease occurred in $18(11.4 \%)$ patients, and $4(2.5 \%)$ patients died. Independent risk factors for recurrence were FIGO stages $>$ I (hazard ratio (HR) 37.1; 95\% confidence interval (Cl) 4.5-155.5), tumor rupture (HR 12.4; 95\% Cl 1.5-61.5), incomplete staging (HR 5.9; 95\% Cl 1.6-21.3), and FSS in patients $<50$ years (HR 8.0; 95\% Cl 2.0-31.6). Conclusion: Intraoperative tumor rupture, incomplete staging, and FSS - all influenced by the surgeon - may impose a substantial recurrence risk. Therefore, careful counseling and balancing of risk and benefit are mandatory before therapy is applied, especially if FSS is planned.
Schlüsselwörter

Borderline-Tumoren · Outcome

\section{Zusammenfassung}

Hintergrund: Das Outcome von Patientinnen mit Borderline-Tumoren (BOT) des Ovars ist generell sehr gut; dennoch können Rezidive und Todesfälle auftreten. Deshalb besteht die Notwendigkeit, prognostische Faktoren zur individuellen Therapieplanung besser zu charakterisieren. Patientinnen und Methoden: Die Daten aller $158 \mathrm{~Pa}-$ tientinnen, die zwischen 1997 und 2008 an einem tertiären Zentrum für gynäkologische Onkologie wegen eines BOT operiert wurden, wurden retrospektiv analysiert. Ergebnisse: Die meisten Patientinnen hatten Tumoren im Frühstadium (FIGO I). Fortgeschrittene Stadien (FIGO II/III) fanden sich bei 23,4\%. Der seröse Typ war am häufigsten vertreten (68\%), gefolgt vom muzinösen Typ (22\%). Alle Patientinnen wurden primär operiert ohne adjuvante systemische Behandlung. 37 Patientinnen $(40,7 \%$ der unter 50 -Jährigen) wurden fertilitätserhaltend operiert. $18(11,4 \%)$ Patientinnen entwickelten ein Rezidiv, 4 (2,5\%) Patientinnen verstarben. Statistisch unabhängige Risikofaktoren für die Entwicklung eines Rezidivs waren ein FIGO-Stadium > I (Hazard Ratio (HR) 37,1; 95\%-Konfidenzinterval (KI) 4,5-155,5), Tumorruptur (HR 12,4; 95\%-KI 1,5-61,5), inkomplettes Staging (HR 5,9; $95 \%-K I$ 1,6-21,3) und fertilitätserhaltendes Vorgehen bei unter 50-Jährigen (HR 8,0; 95\%-KI 2,0-31,6). Schlussfolgerung: Intraoperative Tumorruptur, inkomplettes Staging und fertilitätserhaltendes Vorgehen - Faktoren, die therapeutisch beeinflussbar sind - bedeuten eine deutliche Erhöhung des Rezidivrisikos. Daher sind sorgfältige Aufklärung der Patientin und Abwägung von Nutzen und Risiken der therapeutischen Optionen erforderlich, insbesondere, wenn ein fertilitätserhaltender Eingriff erwogen wird.

\section{KARGER \\ Fax +497614520714 \\ Information@Karger.de}

www.karger.com (c) 2012 S. Karger GmbH, Freiburs

0378-584X/12/0351-0028\$38.00/0

Accessible online at:

www.karger.com/onk
Dr. med. Nina Ewald-Riegler

Klinik für Gynäkologie und Gynäkologische Onkologie HSK, Dr. Horst Schmidt Klinik

Ludwig-Erhard-Str. 100, 65199 Wiesbaden, Germany

Tel. +49 611 43-0, Fax -2952

dr.n.ewri@googlemail.com 


\section{Introduction}

The current understanding of ovarian carcinogenesis distinguishes 2 types of malignancy [1-3]: type I is characterized by low-grade carcinomas (of serous, endometrioid, clear-cell, or mucinous type) and may be diagnosed in localized stages, whereas the high-grade variant type II shows a more aggressive pattern of growth and spread. It includes high-grade serous, endometrioid, or transitional cell types and carcinosarcoma. Type I malignancies are currently believed to develop from precursor lesions including cystadenoma and borderline tumors (BOT). The latter might be of increasing interest because the incidence of BOT has been on the rise in more recent decades $[2,4,5]$. This increase may be explained as a result of improved diagnostic accuracy but could also be due to changing risk profiles [6]. For instance, an increasing use of oral contraceptives may reduce ovarian cancer risk on the one hand, but it is not protective against BOT [7]. According to current knowledge, the general recurrence rate in BOT is about $5 \%$, and mortality is even lower $[2,8,9]$. Generally, the better the prognosis of a neoplasm quoad vitam, the more important become other issues such as quality of life, reproductive function, and maintenance of endocrine function. This applies particularly in the case of BOT, because one third of the patients are under 40 years of age [10] which makes preservation of fertility and endocrine organs an important issue. While radical surgery of BOT may interfere with sustained fertility, conservative surgery also provides a curative treatment in the vast majority of patients [9,11-14], rendering this a viable option even in recurrent cases of BOT [15]. However, an increased risk of recurrence after fertility-sparing surgery (FSS) has been reported [2,11-13]. Therefore, patient counseling with respect to both family planning and oncologic outcome needs to carefully balance both aspects and insert prognostic factors into the overall treatment recommendations. Currently, not many large series have been reported, and the identification of prognostic factors remains an important issue. The clinical tumor registry of the Dr. Horst Schmidt Klinik, Wiesbaden, Germany provides the largest national database of BOT tumors and thus provides an opportunity for the evaluation of treatment outcomes in patients with BOT. Its analysis is presented in this paper.

\section{Patients and Methods}

Patient data for this exploratory analysis were retrieved from the clinical tumor registry established in 2001 at the Dr. Horst Schmidt Klinik, Wiesbaden, Germany. Patients diagnosed between 1997 and 2000 were added retrospectively. The records of all patients are updated annually. The database includes 1,513 patients with ovarian neoplasia treated between 1997 and 2008. 158 (10.4\%) of these patients were entered as having BOT. The diagnosis was made by the resident pathologist (AFE) and in $125(79.1 \%)$ cases confirmed by an external pathology expert (FK); in the remaining 33 (20.9\%) cases, the external pathologist could not be consulted because patients had undergone primary surgery at an external institution and were tumor-free upon restaging so that no tissue blocks could be obtained. Completeness of surgical staging was evaluated according to FIGO guidelines [16] but modified with respect to lymphadenectomy. Complete staging includes removal of all visible tumor tissue, omentectomy, peritoneal washings, resection of all suspicious parts of the peritoneum and representative peritoneal biopsies of the lower, middle and upper part of the peritoneal cavity, and appendectomy (at least in mucinous tumor types). Bilateral pelvic and paraaortic lymph node dissection was not regarded as a necessary part of staging although it is still not excluded from the FIGO guideline. The current status of all patients was updated during August 2010. All data sets were controlled for plausibility and cross-referenced with the original hospital records. Statistical analysis was performed with the SPSS statistical package release 18.0 (SPSS Inc., Chicago, IL, USA). The Kaplan-Meier method was employed for survival analysis, and individual risk factors were tested for significance with a log-rank test and multivariate Cox regression. Hazard ratios (HR) and 95\% confidence intervals (CI) were calculated for adverse events.

\section{Results}

Overall, 158 patients with BOT were identified. The relative incidence of BOT compared to invasive ovarian cancer showed a significant increase from $4.1 \%$ (1997/98) to $16.0 \%$ (2007/08) during the observation period (fig. 1). Patients were followed up for a median of 3.51 years after the initial diagnosis. Patients with BOT were typically aged 40-50 years. The most common histological type was serous followed by mucinous and seromucinous in $67.7,22.2$ and $7.0 \%$ of patients, respectively (table 1). Microinvasion was diagnosed in 7 patients, accounting for $6.5 \%$ of all serous tumors. A micropapillary subtype of serous BOT was observed in 10 patients comprising $9.3 \%$, while intraepithelial cancer occurred in 5 of 35 patients with mucinous BOT $(14.3 \%)$. The vast majority had early stage disease, while more advanced stages (FIGO II and III) were observed in $37(23.4 \%)$ patients; stage FIGO IV was not reported in our cohort. Stage FIGO II/III was defined either by the presence and location of invasive $(n=4)$ or noninvasive implants $(\mathrm{n}=32)$ or by tumors in the lesser pelvis in-

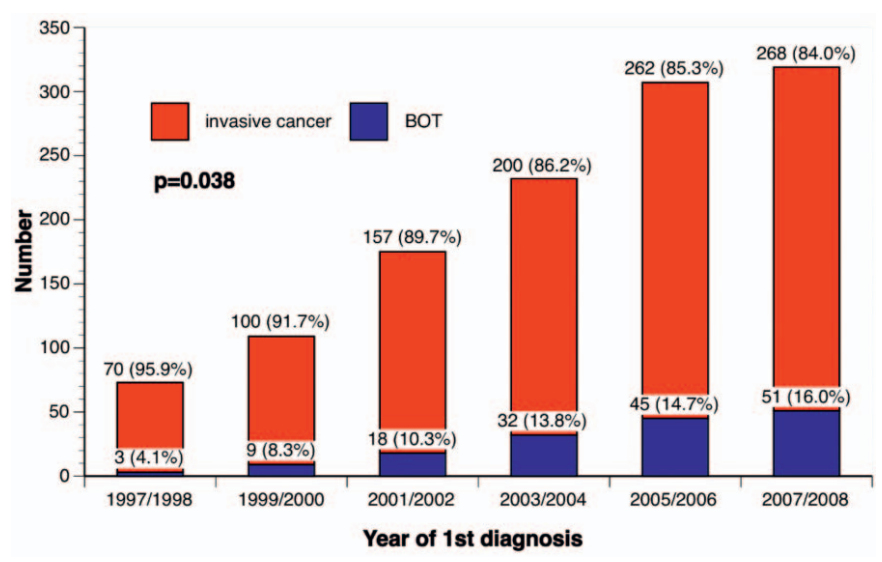

Fig. 1. Frequency of invasive ovarian cancer and borderline tumors (BOT) in the Dr. Horst Schmidt Klinik (HSK) 1997-2008. 
cluding positive cytology $(\mathrm{n}=1)$. The sequence of surgery is displayed in figure 2. Laparoscopic access was chosen in $38.6 \%$ of primary procedures; in $6(3.8 \%)$ additional cases, surgery started as a laparoscopy but had to be converted into an open procedure. During secondary procedures for recurrence therapy or restaging, open access was the method of choice in all cases but one. When open access was chosen, longitudinal incision was usually preferred (87.3\%). Tumor rupture occurred in $15.8 \%$ - exclusively during primary procedures; the rupture incidence was more than twice as high in laparoscopic procedures compared to open operations (10.1 vs. $4.7 \%, \mathrm{p}<0.0001)$. While initial staging was complete in $47(29.7 \%)$ patients, it was assessed as 'incomplete' in 111 $(70.3 \%)$ of the primary procedures. Staging was notably more comprehensive in secondary surgeries (complete in $82.9 \%$ ). The overall incidence of incomplete staging remained $31.0 \%$. Incompleteness of staging was due to the lack of peritoneal biopsy $(20.3 \%$ of all patients and operations, and $65.3 \%$ of cases with incomplete staging), omentum resection (14.6/ $46.9 \%)$, cytology $(10.1 / 32.7 \%)$, and appendectomy (8.2/ $26.5 \%) .76(48.1 \%)$ of all patients underwent secondary surgical procedures after previous incomplete staging. Of these, $4(5.3 \%)$ patients were upstaged (FIGO IC $\rightarrow$ IIA: $n=1$; IIB $\rightarrow$ IIC: $\mathrm{n}=2$; IIB $\rightarrow$ IIIB: $\mathrm{n}=1$ ). 35 patients eligible for restaging refused the procedure; of those, $7(20.0 \%)$ relapsed at a later stage (fig. 2). In 37 patients $(23.4 \%$ of the entire sample or $40.7 \%$ of those under 50 years old), FSS with conservation of the uterus and at least a portion of 1 ovary was performed. Nearly half of these patients $(n=17,45.9 \%)$ had received an incomplete staging. Another 6 of these patients experienced recurrences, resulting in a $35.3 \%$ recurrence rate after FSS and incomplete staging. In contrast, the recurrence rate in those 20 patients with complete staging and FSS was still $25.0 \%(\mathrm{n}=5)$. To date, relapse after FSS has been successfully controlled in all but 1 of the patients. After FSS, 5 pregnancies and 4 child births occurred during the observation period of the present study. After primary therapy, 18 (11.4\%) patients experienced 1 relapse, $6(3.8 \%)$ patients a second relapse, and $4(2.5 \%)$ patients a third relapse. Most relapses occurred within 2 years, but there was a significant proportion $(\mathrm{n}=5,27.8 \%)$ occurring after more than 5 years. The presence of residual tumors was somewhat prevalent after the first operation $(\mathrm{n}=15,9.5 \%)$, but complete resection was reported after further operations in all but 2 patients. Both patients developed recurrences (1 and 3 recurrences, respectively) but were successfully treated and recurrencefree at the final follow-up. Both mortality $(n=4)$ and malignant transformation $(\mathrm{n}=5)$ were rare in the present sample. Recurrence after primary therapy occurred in 18 patients. Out of these 18 patients ( $11.4 \%$ of the total sample), 11 (61.1\%) had undergone FSS, suggesting that this procedure may be associated with a higher risk for a relapse. 3 cases of recurrent disease occurred in patients with serous tumors of the micro-

Table 1. Characteristics of the patient sample

\begin{tabular}{|c|c|}
\hline \multirow{2}{*}{$\begin{array}{l}\text { Age, mean } \pm \text { SD (median, range), years } \\
\text { Age, years }\end{array}$} & $47.3 \pm 14.4(47.8,16-81)$ \\
\hline & Patients, n (\%) \\
\hline$\leq 50$ & $91(57.6)$ \\
\hline$>50$ & $67(42.4)$ \\
\hline \multicolumn{2}{|l|}{ FIGO stage } \\
\hline I & $121(76.6)$ \\
\hline II & $13(8.2)$ \\
\hline III & $24(15.2)$ \\
\hline \multicolumn{2}{|l|}{ Histological tumor type } \\
\hline Serous & $107(67.7)$ \\
\hline Mucinous & $35(22.2)$ \\
\hline Seromucinous & $11(7.0)$ \\
\hline Other & $5(3.2)$ \\
\hline \multicolumn{2}{|l|}{ Additional malignancies } \\
\hline None & $142(89.9)$ \\
\hline Gynecological $^{\mathrm{a}}$ & $5(3.2)$ \\
\hline Breast & $6(3.8)$ \\
\hline Other ${ }^{\mathrm{b}}$ & $5(3.2)$ \\
\hline \multicolumn{2}{|l|}{ Additional histological features } \\
\hline Microinvasion $^{\mathrm{c}}$ & $7(6.5)$ \\
\hline Micropapillary subtype ${ }^{c}$ & $10(9.3)$ \\
\hline Intraepithelial cancer ${ }^{\mathrm{d}}$ & $5(14.3)$ \\
\hline \multicolumn{2}{|l|}{ Non-invasive implants } \\
\hline Total & $32(20.3)$ \\
\hline Epithelial & $2(1.3)$ \\
\hline Desmoplastic & $10(6.3)$ \\
\hline Undifferentiated & $20(12.7)$ \\
\hline Invasive implants & $4(2.5)$ \\
\hline \multicolumn{2}{|l|}{ CA-125 serum concentration } \\
\hline$\leq 35 \mathrm{U} / \mathrm{ml}$ & $29(18.4)$ \\
\hline$>35 \mathrm{U} / \mathrm{ml}$ & $32(20.3)$ \\
\hline $\mathrm{n} / \mathrm{a}$ & 97 (61.4) \\
\hline
\end{tabular}

${ }^{\mathrm{a} C e r v i x}(\mathrm{n}=2)$, endometrium $(\mathrm{n}=3)$.

${ }^{\mathrm{b}}$ Small intestine, bladder, thyroid, kidney, lymphoma $(\mathrm{n}=1$ each).

${ }^{\mathrm{c} P e r c e n t a g e}$ of serous tumors.

${ }^{\mathrm{d}}$ Percentage of mucinous tumors.

$\mathrm{SD}=$ Standard deviation; $\mathrm{n} / \mathrm{a}=$ not applicable.

Fig. 2. Sequence of surgery.

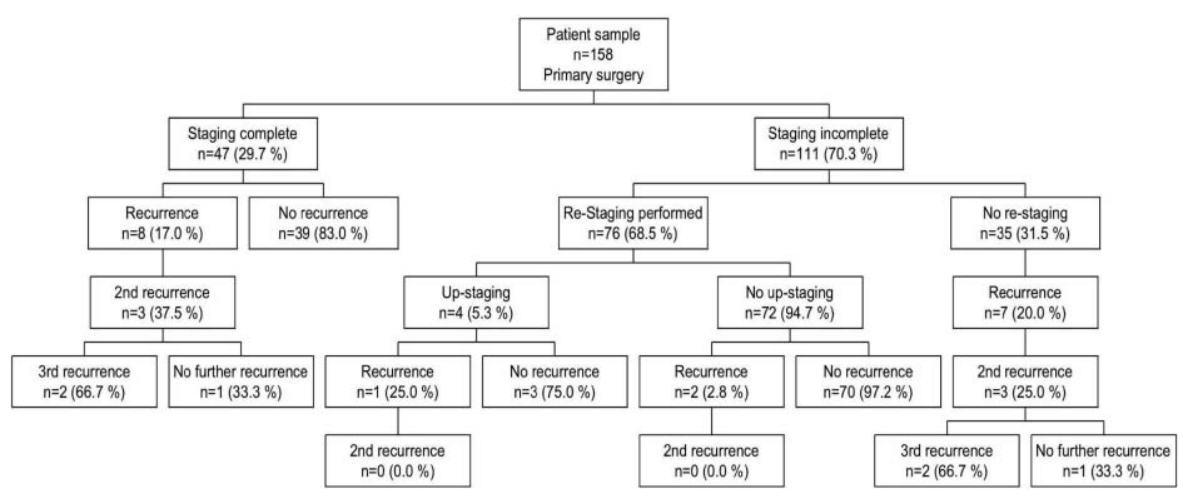


Table 2. Results of multivariate Cox regression for relapse-free survival

\begin{tabular}{lclc}
\hline Criterion & $\begin{array}{l}\text { Recurrences, } \mathrm{n} \\
(\%)\end{array}$ & $\mathrm{p}^{\mathrm{a}}$ & $\mathrm{HR}(95 \% \mathrm{CI})^{\mathrm{a}}$ \\
\hline FIGO stage & $5(4.1 \%)$ & 0.000 & \\
$\quad$ I & $13(35.1 \%)$ & & $37.1(4.5-155.5)$ \\
$\quad$ II/III & $6(5.9 \%)$ & 0.007 & 1 \\
Rupture & $4(14.4 \%)$ & & $12.4(1.5-61.5)$ \\
$\quad$ No & $7(5.8 \%)$ & 0.002 & 1 \\
$\quad$ Yes & $11(29.7 \%)$ & & $5.0(1.8-13.8)$ \\
FSS & $3(5.6 \%)$ & 0.002 & 1 \\
$\quad$ No & $11(29.7 \%)$ & & $8.0(2.0-31.6)$ \\
$\quad$ Yes & $9(8.3 \%)$ & 0.007 & \\
FSS (patients $<50$ years) & & 1 \\
$\quad$ No & $9(18.4 \%)$ & & $5.9(1.6-21.3)$ \\
$\quad$ Yes & & &
\end{tabular}

${ }^{a}$ Multivariate Cox regression.

$\mathrm{HR}=$ Hazard ratio $; \mathrm{CI}=$ confidence interval;

$\mathrm{FSS}=$ fertility-sparing surgery.

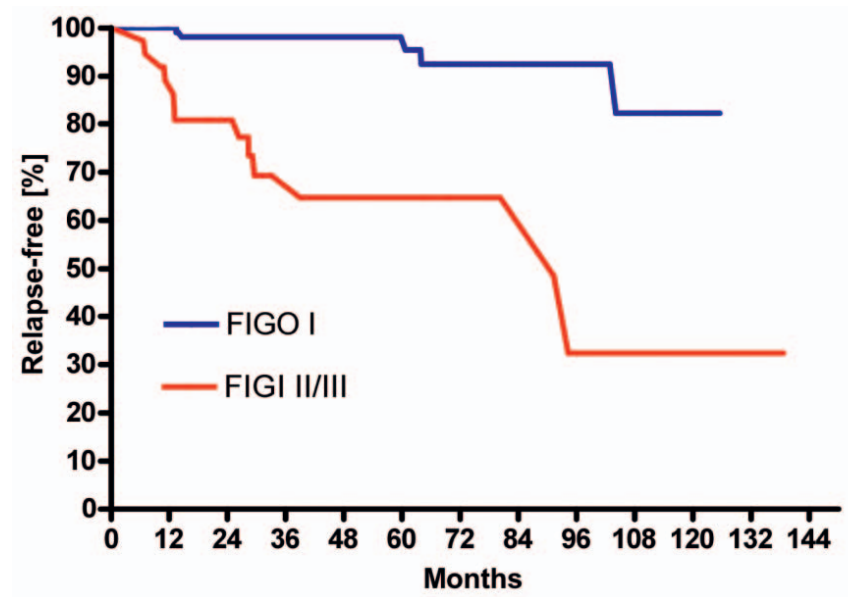

Fig. 3. Cumulative percentage of relapse-free patients depending on FIGO stage.

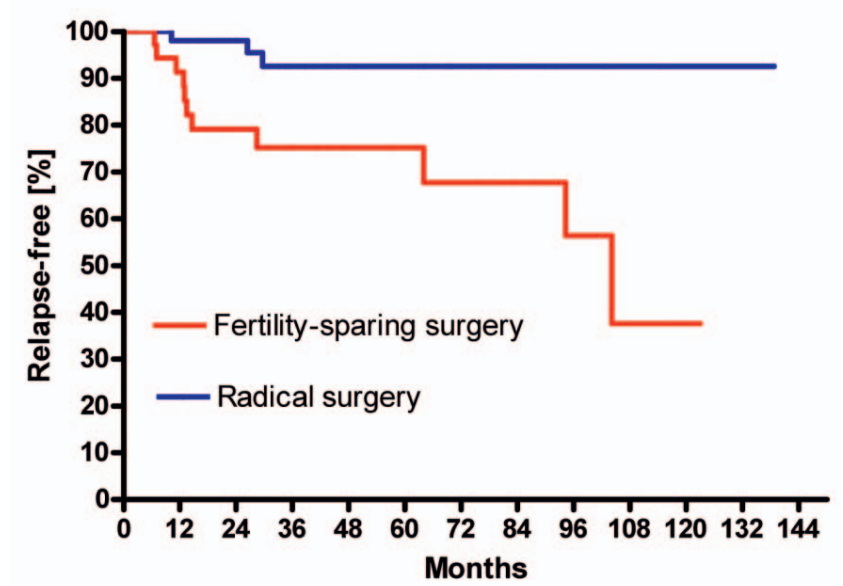

Fig. 4. Cumulative percentage of relapse-free patients depending on the type of surgery (patients $<50$ years). papillary subtype resulting in an incidence of $30.0 \%$. However, 2 of these patients also had FIGO II disease which in itself exerts a substantial recurrence risk. In contrast, 15 recurrences were diagnosed in patients with other histotypes $(10.9 \%)(p=0.074)$. Microinvasion did not show a significant association with recurrence risk: $14.3 \%(\mathrm{n}=1)$ with and $11.3 \%$ of patients without microinvasion experienced a relapse. Multivariate statistics identified 4 prognostic factors promoting recurrence of BOT of the ovary (table 2). The greatest HR was observed for advanced clinical stages: the development of a recurrence was 37.1 times more likely (95\% CI 4.5-155.5) for FIGO II/III as compared to FIGO I (fig. 3). Further factors significantly predisposing for relapse were the occurrence of tumor rupture during surgery, incomplete staging, and FSS. When patients over 50 years of age were excluded, the HR for FSS was even higher (HR 8.0; 95\% CI 2.0-31.6) (fig. 4). Especially in combination, the aforementioned factors increased the risk of recurrence: all 3 patients with FIGO II/III tumors, who underwent FSS with incomplete staging, developed at least 1 recurrence during the observation period. On the other hand, in a total of 94 radically treated patients with FIGO I tumors, only 1 recurrence was observed, and this occurred after incomplete staging.

\section{Discussion}

The increase in the incidence of BOT of the ovary in comparison to invasive carcinoma observed in the present study is in accordance with the annual FIGO World Reports and other published studies [4-6, 8], and reflects a trend observed since the late 1970s [4]. Since chemo- or radiotherapy are currently not believed to play a role in the treatment of BOT of the ovary $[2,17]$, the quality of surgical proceedings is the all-important determinant of prognosis. Overall, prognosis is excellent, and a fatal course of the disease is very rare. Despite the fact that recurrences can often be treated successfully, the relapse of a BOT is a serious and in some cases life-threatening event that should be avoided. Overall, the recurrence rate in the present study is largely in accordance with results published so far. A systematic review recently found a recurrence rate of $4.9 \%$ after radical surgery in 3,847 patients, and $15.2 \%$ after conservative surgery in 2,913 patients [2]. The slightly higher recurrence rate after fertility preservation in our cohort may be explained by a much higher percentage of advanced FIGO stages: $37.0 \%$ of the patients undergoing conservative surgery were in FIGO stages II/III as compared to only $8.8 \%$ in the aforementioned review. However, the increased risk of recurrence after tumor rupture and incomplete staging also demonstrates the crucial importance of surgical diligence and guideline adherence. Unlike the FIGO stage and the issue of fertility preservation, avoidance of tumor rupture and completeness of staging are largely controlled by the surgeon. One of the key risk factors of tumor rupture is 
laparoscopic access. The known increased rupture risk during laparoscopic procedures was confirmed by our results $[2,18]$. The statistical independence of this influence implies an effect that is not explained by the potentially poorer staging quality that is sometimes associated with laparoscopic access [2, 19, 20]. Since BOT are frequently only identified during surgery (for a suspected non-malignant lesion), the surgical access route is often already chosen upon presentation of the problem. Therefore the intrinsic rupture risk of laparoscopic operations cannot always be avoided; it should, however, command caution when additional factors are present. Staging quality in our cohort was less than ideal, especially in primary procedures, and incomplete surgical staging was an independent risk factor for recurrence with a HR on a par with that of FSS. In up to $50 \%$ of cases, occult metastases of BOT are identified during comprehensive staging [21, 22], and the frequency of upstaging during restaging surgery is considerable, albeit very variable [2, 23-25]. However, the influence of staging quality on the prognosis is a matter of substantial controversy. While some authors report a higher incidence of recurrence after incomplete staging [26], others deny an appreciable difference $[19,23,27,28]$. The fact that incomplete staging occurs frequently during primary surgical procedures is hardly surprising, given the fact that in most cases BOT is histologically diagnosed post hoc. Hence, the high percentage found in the present study (which is in line with other studies [20, 29]) indicates more a procedural necessity than poor quality. Moreover, complete staging requires the consent of the patient for a secondary surgical procedure, which cannot always be obtained. However, the overall rate of incomplete staging of $31 \%$ certainly indicates room for improvement. An increased risk of recurrence in the micropapillary subtype, as reported in the literature [30-32], could not be confirmed in the present study, but the number of patients with FIGO I tumors of this type $(n=6)$ was too low to warrant valid con- clusions. Moreover, according to Prat and Nictolis [33], the prognostic significance of this type may only be relevant in combination with invasive implants. Despite the large body of published evidence, there are several issues that require better understanding and/or improved strategies in the treatment of BOT [2,34]. First of all, many published studies are marred by a relatively low number of patients and/or short observation periods $[2,17]$. The significant proportion of recurrences occurring after more than 5 years in the present study suggests that recurrence is a time-dependent process, and thus the published relapse percentages including our own observations may be too low. Accordingly, Silva et al. [35] recommended a follow-up of at least 10 years for recurrence and 20 years for survival. Moreover, the important issues of fertility preservation, surgical access (open vs. laparoscopic), and complete staging are not without controversy. Our results confirm already published evidence that FSS creates a significant risk for recurrence in BOT. Therefore, patients who wish to retain fertility should be carefully counseled about risks and the inconvenience of complex aftercare (e.g. compliance with follow-up examinations and/or operations). However, FSS should - in light of the curative treatment options for recurrent BOT - not be disregarded merely because of the higher relapse rate [36-39]. There are still certain limitations to the present study as it is a retrospective analysis with a possible bias. And even though up to now it presents the largest patient series nationwide, the number of cases is still low. Thus, in order to verify the obtained data, a multicenter study is crucial.

\section{Disclosure Statement}

The authors declare no conflicts of interest.

\section{References}

1 Kurman RJ, Shih IeM: The origin and pathogenesis of epithelial ovarian cancer: a proposed unifying theory. Am J Surg Pathol 2010;34:433-443.

2 Du Bois A, Ewald-Riegler N, du Bois O, Harter P: Borderline-Tumoren des Ovars - eine systematische Übersicht. Geburtsh Frauenheilk 2009;69: 807-833

-3 Lengyel E: Ovarian cancer development and metastasis. Am J Pathol 2010;177:1053-1064.

4 Harlow BL, Weiss NS, Lofton S: Epidemiology of borderline ovarian tumors. J Natl Cancer Inst 1987; 78:71-74.

$\checkmark 5$ Heintz AP, Odicino F, Maisonneuve P, Quinn MA, Benedet JL, Creasman WT, Ngan HY, Pecorelli S, Beller U: Carcinoma of the ovary. FIGO 6th Annual Report on the Results of Treatment in Gynecological Cancer. Int J Gynaecol Obstet 2006;95(suppl 1):S161-192.

6 Skírnisdóttir I, Garmo H, Wilander E, Holmberg L: Borderline ovarian tumors in Sweden 1960-2005: trends in incidence and age at diagnosis compared to ovarian cancer. Int J Cancer 2008;123:18971901.
7 Beral V, Doll R, Hermon C, Peto R, Reeves G: Ovarian cancer and oral contraceptives: collaborative reanalysis of data from 45 epidemiological studies including 23,257 women with ovarian cancer and 87,303 controls. Lancet 2008;371:303-314.

8 Akeson M, Zetterqvist BM, Dahllöf K, Jakobsen AM, Brännström M, Horvath G: Population-based cohort follow-up study of all patients operated for borderline ovarian tumor in western Sweden during an 11-year period. Int J Gynecol Cancer 2008; 18:453-459.

9 Chan JK, Lin YG, Loizzi V, Ghobriel M, DiSaia PJ, Berman ML: Borderline ovarian tumors in reproductive-age women. Fertility-sparing surgery and outcome. J Reprod Med 2003;48:756-760.

10 Sherman ME, Mink PJ, Curtis R, Cote TR, Brooks S, Hartge P, Devesa S: Survival among women with borderline ovarian tumors and ovarian carcinoma: a population-based analysis. Cancer 2004;100:1045-1052.

11 Ayhan A, Guvendag Guven ES, Guven S, Kucukali $\mathrm{T}$ : Recurrence and prognostic factors in borderline ovarian tumors. Gynecol Oncol 2005;98:439-445.
12 Cadron I, Leunen K, Van Gorp T, Amant F, Neven $\mathrm{P}$, Vergote I: Management of borderline ovarian neoplasms. J Clin Oncol 2007;25:2928-2937.

13 Gotlieb WH, Flikker S, Davidson B, Korach Y, Kopolovic J, Ben-Baruch G: Borderline tumors of the ovary: fertility treatment, conservative management, and pregnancy outcome. Cancer 1998;82: 141-146.

14 Lenhard MS, Mitterer S, Kumper C, Stieber P, Mayr D, Ditsch N, Friese K, Burges A: Long-term follow-up after ovarian borderline tumor: relapse and survival in a large patient cohort. Eur J Obstet Gynecol Reprod Biol 2009;145:189-194.

15 Cheng B, Wan X, Qian X, Lv W, Xie X: Results of conservative surgery for recurrent borderline ovarian tumors. Eur J Gynaecol Oncol 2009;30:75-78.

16 Benedet JL, Bender H, Jones H, 3rd, Ngan HY, Pecorelli S: FIGO staging classifications and clinical practice guidelines in the management of gynecologic cancers. FIGO Committee on Gynecologic Oncology. Int J Gynaecol Obstet 2000;70:209-262. 
17 Faluyi O, Mackean M, Gourley C, Bryant A, Dickinson HO: Interventions for the treatment of borderline ovarian tumours. Cochrane Database Syst Rev 2010;(9):CD007696.

18 Havrilesky LJ, Peterson BL, Dryden DK, Soper JT, Clarke-Pearson DL, Berchuck A: Predictors of clinical outcomes in the laparoscopic management of adnexal masses. Obstet Gynecol 2003;102:243-251.

19 Fauvet R, Boccara J, Dufournet C, Poncelet C, Daraï E: Laparoscopic management of borderline ovarian tumors: results of a French multicenter study. Ann Oncol 2005;16:403-410.

20 Desfeux P, Camatte S, Chatellier G, Blanc B, Querleu D, Lécuru F: Impact of surgical approach on the management of macroscopic early ovarian borderline tumors. Gynecol Oncol 2005;98:390-395.

21 Fadare O: Recent developments on the significance and pathogenesis of lymph node involvement in ovarian serous tumors of low malignant potential (borderline tumors). Int J Gynecol Cancer 2009;19:103-108.

22 Lin PS, Gershenson DM, Bevers MW, Lucas KR, Burke TW, Silva EG: The current status of surgical staging of ovarian serous borderline tumors. Cancer 1999;85:905-911.

23 Anfinan N, Sait K, Ghatage P, Nation J, Chu P: Ten years experience in the management of borderline ovarian tumors at Tom Baker Cancer Centre. Arch Gynecol Obstet 2011;284:731-735.

-24 Zapardiel I, Rosenberg P, Peiretti M, Zanagnolo V, Sanguineti F, Aletti G, Landoni F, Bocciolone L, Colombo N, Maggioni A: The role of restaging borderline ovarian tumors: single institution experience and review of the literature. Gynecol Oncol 2010;119:274-277.

25 Fauvet R, Boccara J, Dufournet C, David-Montefiore E, Poncelet C, Darai E: Restaging surgery for women with borderline ovarian tumors: results of a French multicenter study. Cancer 2004;100:1145-1151.

26 Morris RT, Gershenson DM, Silva EG, Follen M, Morris M, Wharton JT: Outcome and reproductive function after conservative surgery for borderline ovarian tumors. Obstet Gynecol 2000;95:541-547.

27 Cho YH, Kim DY, Kim JH, Kim YM, Kim KR, Kim YT, Nam JH: Is complete surgical staging necessary in patients with stage I mucinous epithelial ovarian tumors? Gynecol Oncol 2006;103:878-882.

28 Yokoyama Y, Moriya T, Takano T, Shoji T, Takahashi O, Nakahara K, Yamada $\mathrm{H}$, Yaegashi $\mathrm{N}$, Okamura $\mathrm{K}$, Izutsu $\mathrm{T}$, Sugiyama $\mathrm{T}$, Tanaka $\mathrm{T}$, Kurachi H, Sato A, Tase T, Mizunuma H: Clinical outcome and risk factors for recurrence in borderline ovarian tumours. Br J Cancer 2006;94:1586-1591.

29 Coumbos A, Sehouli J, Chekerov R, Schaedel D, Oskay-Oezcelik G, Lichtenegger W, Kuehn W: Clinical management of borderline tumours of the ovary: results of a multicentre survey of 323 clinics in Germany. Br J Cancer 2009;100:1731-1738.

-30 Eichhorn JH, Bell DA, Young RH, Scully RE: Ovarian serous borderline tumors with micropapillary and cribriform patterns: a study of 40 cases and comparison with 44 cases without these patterns. Am J Surg Pathol 1999;23:397-409.

31 Chang SJ, Ryu HS, Chang KH, Yoo SC, Yoon JH: Prognostic significance of the micropapillary pattern in patients with serous borderline ovarian tumors. Acta Obstet Gynecol Scand 2008:87:476-481.

- 32 Longacre TA, McKenney JK, Tazelaar HD, Kempson RL, Hendrickson MR: Ovarian serous tumors of low malignant potential (borderline tumors): outcomebased study of 276 patients with long-term ( $>$ or $=5$-year) follow-up. Am J Surg Pathol 2005;29:707-723.

33 Prat J, De Nictolis M: Serous borderline tumors of the ovary: a long-term followup study of 137 cases, including 18 with a micropapillary pattern and 20 with microinvasion. Am J Surg Pathol 2002;26:1111-1128.

-34 Sehouli J, Oskay-Oezcelik G, Pietzner K, Chen F, Coumbos A, Darb-Esfahani S, Schuback B, Heinrich G, Kronenberger C, Lorsbach M, Lichtenegger W, Chekerov R: Clinical management of borderline tumours of the ovary - experience from the 'Berlin online tumour conference for gynaecological malignancies'. Anticancer Res 2010;30:1701-1706.

35 Silva EG, Gershenson DM, Malpica A, Deavers M: The recurrence and the overall survival rates of ovarian serous borderline neoplasms with noninvasive implants is time dependent. Am J Surg Pathol 2006;30:1367-1371.

36 Park JY, Kim DY, Kim JH, Kim YM, Kim YT, Nam JH: Surgical management of borderline ovarian tumors: the role of fertility-sparing surgery. Gynecol Oncol 2009;113:75-82.

- 37 Marcickiewicz J, Brännström M: Fertility preserving surgical treatment of borderline ovarian tumour: long-term consequence for fertility and recurrence. Acta Obstet Gynecol Scand 2006;85:1496-1500.

38 Tinelli FG, Tinelli R, La Grotta F, Tinelli A, Cicinelli E, Schönauer MM: Pregnancy outcome and recurrence after conservative laparoscopic surgery for borderline ovarian tumors. Acta Obstet Gynecol Scand 2007;86:81-87.

39 Nam JH: Borderline ovarian tumors and fertility. Curr Opin Obstet Gynecol 2010;22:227-234. 